\title{
Peptide hydrolase system of lactic acid bacteria isolated from Serra da Estrela cheese
}

\author{
Angela C. Macedo ${ }^{\mathrm{a}, \mathrm{b}}$, Marta Vieira ${ }^{\mathrm{a}}$, Raquel Poças ${ }^{\mathrm{a}}$, F. Xavier Malcata ${ }^{\mathrm{a}, *}$ \\ ${ }^{a}$ Escola Superior de Biotecnologia, Universidade Católica Portuguesa, Rua Dr. António Bernardino de Almeida, P-4200-072 Porto, Portugal \\ ${ }^{\mathrm{b}}$ Instituto Superior da Maia, Avenida Carlos Oliveira Campos, Castelo da Maia, P-4470 Maia, Portugal
}

\begin{abstract}
Lactobacillus paracasei subsp. paracasei ESB 230, Leuconostoc mesenteroides subsp. mesenteroides ESB 136, Lactococcus lactis subsp. lactis ESB 117 and Enterococcus faecium ESB 50, previously isolated from certified Serra da Estrela cheeses, were tested for their aminopeptidase, dipeptidyl aminopeptidase, endopeptidase, dipeptidase and carboxypeptidase activities. The crude cell-free extracts (CFE) of Lb. paracasei ESB 230 exhibited the highest aminopeptidase activity, followed by CFE of Leuc. mesenteroides ESB 136 and, at last, by CFE of L. lactis ESB 117; the aminopeptidase activity in CFE of Ent. faecium was practically non-existent. The four CFE studied also showed appreciable carboxypeptidase activities, although these were lower than their dipeptidase counterparts; in addition, their dipeptidyl aminopeptidase and endopeptidase activities were lower than their aminopeptidase activities. Dipeptides consisting of hydrophobic amino acid residues (i.e. leucine, methionine and phenylalanine) were more rapidly attacked by all CFE than those with hydrophilic amino acid residues. The peptide hydrolase system of CFE of Lb. paracasei ESB 230 was qualitatively quite similar to, but quantitatively more active than that of CFE of Leuc. mesenteroides ESB 136 (except for the endopeptidase); additionally, the CFE of L. lactis ESB 117 and of Ent. faecium ESB 50 were quite distinct from each other, and from the other two CFE tested. (C) 2001 Elsevier Science Ltd. All rights reserved.
\end{abstract}

Keywords: Dairy foods; Lactic acid bacteria; Peptidase activity

\section{Introduction}

The lactic acid bacteria (LAB) currently employed to ferment milk are nutritionally fastidious; they have complex free amino acid requirements if sustained maximum growth rates are to be assured, as they cannot synthesise several amino acids (Thomas \& Pritchard, 1987). The concentration of free amino acids in milk is insufficient to support optimal LAB growth. Consequently, these bacteria have developed complex enzyme systems, which bring about production of small peptides and release of free amino acids starting from the large peptides in their immediate environment (Christensen, Dudley, Pederson, $\&$ Steele, 1999). In cheese, these large- and intermediatesized peptides are primarily produced by residual rennet, and to a lesser extent by native plasmin, as a result of

\footnotetext{
* Corresponding author.

E-mail address: xmalcata@esb.ucp.pt (F.X. Malcata).
}

degradation of caseins, the major proteins in that fermented food (Fox \& McSweeney, 1996). The resulting small peptides are eventually transported into the cytoplasm. Once inside the cell, peptides are degraded to free amino acids by endocellullar peptidases (such as aminopeptidases, dipeptidases and carboxypeptidases). Finally, the amino acids are catabolised by bacteria thus forming intermediate compounds and eventually inorganic nitrogen. On the other hand, free amino acids have a direct (although probably limited) contribution to cheese flavour development, as well as an indirect contribution via formation of the aforementioned catabolic metabolites (such as amines, thiols, thioesters, aldehydes and ketones) (Cogan \& Hill, 1995).

The peptide hydrolase system of Lactococcus spp. and Lactobacillus spp. has been the focus of several studies (Bockelmann, 1995; Fox \& McSweeney, 1996; Christensen et al., 1999). However, little attention has to date been directed to the peptidases of Leuconostoc spp., despite the fact that this genus is a part of starter cultures designed for the manufacture of several cheese varieties, viz. 
Dutch-type cheeses (El-Shafei, El-Soda, \& Ezzat, 1990). Additionally, studies on peptidase activities of Enterococcus spp., which have been proven to contribute to cheese ripening, viz. Italian-type cheeses (Prato \& Messina, 1990), are also scarce.

Among lactic acid bacteria found in Serra da Estrela cheese (the most famous Portuguese traditional cheese, manufactured from raw ovine milk via coagulation by dry flowers of the wild thistle), Lactobacillus paracasei subsp. paracasei and Lactococcus lactis subsp. lactis are the dominant species; Leuconostoc mesenteroides subsp. mesenteroides and Enterococcus faecium have also been found, but to lower levels (Macedo, Malcata, \& Hogg, 1995; Tavaria \& Malcata, 1998). Considering that the lactic acid bacteria found in raw milk cheeses are fundamentally different from those present in commercial starters (Requena, Pelaez, \& Desmazeaud, 1991), this study was designed so as to investigate (and duly compare) the peptidase system in crude cell-free extracts of wild strains belonging to the dominant groups of lactic acid bacteria in Serra da Estrela cheese.

\section{Materials and methods}

\subsection{Strains, growth conditions and harvesting}

The strains used in this study were Lactobacillus paracasei subsp. paracasei ESB 230, Leuconostoc mesenteroides subsp. mesenteroides ESB 136, Lactococcus lactis subsp. lactis ESB 117 and Enterococcus faecium ESB 50. These strains had been isolated from Serra da Estrela cheese, as described previously by Tavaria and Malcata (1998), and tentatively identified using chemotaxonomical kits (API $50 \mathrm{CHL}$ and API STREP, Biomérieux, France). The harvested cells of such strains were stored at $-80^{\circ} \mathrm{C}$ as stock solutions in $30 \%(\mathrm{v} / \mathrm{v})$ aqueous glycerol.

Inoculation with $1 \%(\mathrm{v} / \mathrm{v})$ stock culture of $L$. lactis $\mathrm{ESB}$ 117 or Ent. faecium ESB 50 was performed in $10 \mathrm{~mL}$ of M17 broth (Merck, Darmstad, Germany), whereas Lb. paracasei ESB 230 and Leuc. mesenteroides ESB 136 were inoculated in $10 \mathrm{~mL}$ of MRS broth (Merck). After incubation at $30^{\circ} \mathrm{C}$ for ca. $16 \mathrm{~h}$, these micro-organisms were subcultured similarly in the same medium $(250 \mathrm{~mL})$. A final inoculation of $5 \%(\mathrm{v} / \mathrm{v})$ in $5 \mathrm{~L}$ of fresh medium was subsequently made; the medium was then incubated overnight (at $30^{\circ} \mathrm{C}$ and for ca. $14 \mathrm{~h}$ ). All strains were harvested (at late exponential phase) at $4^{\circ} \mathrm{C}$ by centrifugation for $10 \mathrm{~min}$ at $5860 \times \mathrm{g}$ (El-Soda \& Desmazeaud, 1982).

\subsection{Preparation of crude cell-free extract}

Harvested cells were washed twice in $0.01 \mathrm{~m}$ potassium phosphate buffer ( $\mathrm{pH}$ 7.0). Cells were then collected by centrifugation at $13,180 \times g$ for $50 \mathrm{~min}$, and disrupted by grinding with alumina (type 305, from Sigma, St. Louis MO, USA) using a mortar and pestle, at a 1:5 weight ratio of pellet to alumina. The extracts were suspended at $5 \%(\mathrm{v} / \mathrm{v})$ in $0.01 \mathrm{M}$ potassium phosphate buffer (pH 7.0), and both the alumina and the cell debris were removed by centrifugation at $4^{\circ} \mathrm{C}$ for $40 \mathrm{~min}$ at $14,680 \times g$. The supernatants obtained, designated hereafter as crude cell-free extracts (CFE), were kept frozen at $-30^{\circ} \mathrm{C}$ in several Eppendorf vials until the enzyme assays were done. Prior to freezing, the activity of lactate dehydrogenase was determined (Lactate Dehydrogenase Kit No. 340-LD, from Sigma) to check for the degree of cell lysis (Requena, Pelaez, \& Fox, 1993).

\subsection{Determination of protein concentration}

The micro protein determination kit traded by Sigma (Kit No. 690-A) was used to quantitate the protein concentration in the CFE using bovine serum albumin as standard (Ohnishi \& Barr, 1978).

\subsection{Aminopeptidase, dipeptidyl aminopeptidase and endopeptidase activities}

The aminopeptidase activities were measured using the following substrates, all dissolved to a final concentration of $16 \mathrm{~mm}$ in methanol: Ala-p-nitroanilide (Ala-pNA), Arg-pNA, Glu-pNA, Gly-pNA, Leu-pNA, Lys-pNA, Met-pNA, Pro-pNA and Val-pNA. Dipeptidyl aminopeptidase activity was determined using Arg-Pro-pNA, Gly-Phe-pNA, Gly-Pro-pNA and Phe-Val-pNA, all dissolved to a final concentration of $4 \mathrm{~mm}$ in methanol. Endopeptidase activity was assayed using $N$-BenzoylArg- $p$-nitroanilide (NBZ-Arg-pNA), NBZ-Tyr-pNA and NBZ-Pro-Phe-Arg-pNA, all dissolved to a final concentration of $16.4 \mathrm{~mm}$ in methanol. All these chemicals, obtained from Sigma, were reagent grade or better, and were used without further purification.

The reaction mixture, consisting of $2.8 \mathrm{~mL}$ potassium phosphate buffer $(0.1 \mathrm{M}, \mathrm{pH} 7.0), 0.1 \mathrm{~mL}$ substrate solution and $0.1 \mathrm{~mL} \mathrm{CFE}$, was incubated at $37^{\circ} \mathrm{C}$ for up to $6 \mathrm{~h}$. Absorbance of the $p$-nitroanilide moiety released throughout time was monitored at $410 \mathrm{~nm}$ at irregular time intervals. Enzyme and substrate blanks were also monitored under the same incubation conditions. The assays were repeated for two different concentrations of CFE. The concentration of $p$-nitroanilide released was calculated from a calibration curve prepared in advance. The activity was considered to equal the slope of the straight line fitted to the concentration of pNA ( $\mu \mathrm{mol})$ versus time (h) data, where the two concentrations of CFE were considered as distinct datum points in the same plot. The specific activity was expressed as $\mu$ mole of substrate hydrolysed $\mathrm{h}^{-1}$ and $\mathrm{mg}^{-1}$ of protein (i.e. the value of the activity divided by the protein concentration of CFE). 


\subsection{Dipeptidase and carboxypeptidase activities}

The dipeptides Pro-Gly, Pro-Leu, Pro-Met, Gly-Pro, Phe-Pro, Val-Pro, Leu-Ser, Lys-Leu, Trp-Leu, PheGly, Ala-Phe, Tyr-Phe, Gly-Tyr, Arg-Val, Glu-Val and Met-Gly (all dissolved to a final concentration of $2.5 \mathrm{~m}$ in $0.1 \mathrm{~m}$ potassium phosphate buffer, $\mathrm{pH}$ 7.0) were used as substrates in the assays for dipeptidase activity. The substrates hippuryl-Arg (HIP-Arg), HIP-Phe and HIP-Arg-Gly, all dissolved to a final concentration of $2.5 \mathrm{M}$ in $0.1 \mathrm{M}$ potassium phosphate buffer $(\mathrm{pH} 7.0)$, were employed as substrates to quantitate carboxypeptidase activity. All chemicals, obtained from Sigma, were reagent grade or better, and were used without further purification. The reaction mixture, consisting of $1.8 \mathrm{~mL}$ substrate solution and $0.2 \mathrm{~mL}$ CFE, was incubated at $37^{\circ} \mathrm{C}$ for up to $6 \mathrm{~h}$. Aliquots $(50 \mu \mathrm{L})$ were periodically taken, mixed with $\mathrm{Cd}$-ninhydrin reagent $(2 \mathrm{~mL})$, and incubated at $84^{\circ} \mathrm{C}$ for 5 min (Folkertsma \& Fox, 1992). Enzyme and substrate blanks were also monitored under the same incubation conditions. The extent of release of amino acids was assayed by measuring absorbance at $507 \mathrm{~nm}$. The concentration of free amino acids was calculated from calibration curves prepared in advance for the amino acid residues present in each substrate. The assays were repeated for two different concentrations of CFE. The activity was considered to equal the slope of the straight line fitted to the concentration of amino acid ( $\mu$ mole) versus time (h) data, where the two concentrations of CFE were considered as distinct datum points in the same plot. The specific activity was again expressed as $\mu \mathrm{mol}$ of substrate hydrolysed $\mathrm{h}^{-1}$ and $\mathrm{mg}^{-1}$ of protein.

\section{Results}

\subsection{Aminopeptidase activity}

Table 1 shows the results for the aminopeptidase specific activity of the crude cell-free extracts tested. No activity was recorded on Glu-pNA, Gly-pNA or Pro-pNA for any of the extracts studied, whereas Val-pNA activity was detected only for CFE of $L b$. paracasei ESB 230. Observing the specific activities of CFE of lactic acid bacteria toward the other substrates, one observed that CFE of Ent. faecium ESB 50 only exhibited aminopeptidase activity on two substrates (Arg-pNA and Met-pNA), and CFE of $L b$. paracasei ESB 230 exhibited the highest aminopeptidase activities, followed by CFE of Leuc. mesenteroides ESB 136 and, at last, CFE of $L$. lactis ESB 117. The substrates Arg-pNA, Leu-pNA and Lys-pNA were the substrates hydrolysed at the highest rate (under condition of saturation by substrate) by $\mathrm{CFE}$ of Lb. paracasei ESB 230 and Leuc. mesenteroides ESB 136, whereas Met-pNA and Arg-pNA were the substrates more rapidly taken up by CFE of L. lactis ESB 117 and Ent. faecium ESB 50.

\subsection{Dipeptidyl aminopeptidase activity}

The results for the dipeptidyl aminopeptidase specific activity of CFE of the strains tested are shown in Table 2. The substrate Phe-Val-pNA was not hydrolysed by any of the CFE considered, whereas Gly-Phe-pNA was attacked by all. The substrate Arg-Pro-pNA was only hydrolysed by CFE of Lb. paracasei ESB 230 and Leuc. mesenteroides ESB 136, whereas Gly-Pro-pNA was

Table 1

Aminopeptidase specific activity ${ }^{\text {a }}$ (average \pm standard error) of crude cell-free extract (CFE) of lactic acid bacteria isolated from Serra da Estrela cheese

\begin{tabular}{lllll}
\hline Substrate-pNA & \multicolumn{2}{l}{ Lactic acid bacteria CFE } & & \\
\cline { 2 - 5 } & ESB230 & ESB136 & ESB117 & ESB50 \\
\hline Ala & $0.0203 \pm 0.0056$ & $0.0072 \pm 0.0021$ & $0.0014 \pm 0.0003$ & n.d. \\
Arg & $0.0495 \pm 0.0107$ & $0.0476 \pm 0.0148$ & $0.0043 \pm 0.0009$ & $0.0009 \pm 0.0002$ \\
Glu & n.d. ${ }^{\text {d }}$ & n.d. & n.d. & n.d. \\
Gly & n.d. & n.d. & n.d. & n.d. \\
Leu & $0.0564 \pm 0.0129$ & $0.0172 \pm 0.0048$ & $0.0006 \pm 0.0001$ & n.d. \\
Lys & $0.0808 \pm 0.0174$ & $0.0698 \pm 0.0202$ & $0.0011 \pm 0.0002$ & n.d. \\
Met & $0.0173 \pm 0.0040$ & $0.0072 \pm 0.0021$ & $0.0045 \pm 0.0008$ & $0.0060 \pm 0.0016$ \\
Pro & n.d. & n.d. & n.d. & n.d. \\
Val & $0.0047 \pm 0.0011$ & n.d. & n.d. & n.d. \\
\hline
\end{tabular}

${ }^{\text {a }}$ Specific activity expressed as $\mu \mathrm{mol}$ of substrate $\mathrm{h}^{-1} \mathrm{mg}^{-1}$ of protein.

${ }^{\mathrm{b}}$ ESB230: Lactobacillus paracasei subsp. paracasei; ESB136: Leuconostoc mesenteroides subsp. mesenteroides; ESB117: Lactococcus lactis subsp. lactis; ESB50: Enterococcus faecium.

${ }^{\mathrm{c}} \mathrm{pNA}=p$-nitroanilide.

${ }^{\mathrm{d}}$ n.d. $=$ not detected. 
Table 2

Dipeptidyl aminopeptidase specific activity ${ }^{\text {a }}$ average \pm standard error) of crude cell-free extract (CFE) of lactic acid bacteria isolated from Serra da Estrela cheese

\begin{tabular}{lllll}
\hline Substrate-pNA & \multicolumn{2}{l}{ Lactic acid bacteria CFE } & & \\
\cline { 2 - 5 } & ESB230 & ESB136 & ESB117 & ESB50 \\
\hline Arg-Pro & $0.0240 \pm 0.0064$ & $0.0011 \pm 0.0005$ & n.d. $^{\text {d }}$ & n.d. \\
Gly-Phe & $0.0023 \pm 0.0005$ & $0.0031 \pm 0.0010$ & $0.0013 \pm 0.0003$ & $0.0017 \pm 0.0004$ \\
Gly-Pro & $0.0050 \pm 0.0012$ & n.d. & n.d. & n.d. \\
Phe-Val & n.d. & n.d. & n.d. & n.d. \\
\hline
\end{tabular}

${ }^{\mathrm{a}}$ Specific activity expressed as $\mu \mathrm{mol}$ of substrate $\mathrm{h}^{-1} \mathrm{mg}^{-1}$ of protein.

${ }^{\mathrm{b}}$ ESB230: Lactobacillus paracasei subsp. paracasei; ESB136: Leuconostoc mesenteroides subsp. mesenteroides; ESB117: Lactococcus lactis subsp. lactis; ESB50: Enterococcus faecium.

${ }^{\mathrm{c}} \mathrm{pNA}=p$-nitroanilide.

${ }^{\mathrm{d}}$ n.d. $=$ not detected.

Table 3

Endopeptidase specific activity ${ }^{\mathrm{a}}$ (average \pm standard error) of crude cell-free extract (CFE) of lactic acid bacteria isolated from Serra da Estrela cheese

\begin{tabular}{|c|c|c|c|c|}
\hline \multirow[t]{2}{*}{ NBZ-substrate-pNA ${ }^{c}$} & \multicolumn{4}{|c|}{ Lactic acid bacteria $\mathrm{CFE}^{\mathrm{b}}$} \\
\hline & ESB230 & ESB136 & ESB117 & ESB50 \\
\hline Arg & $0.0037 \pm 0.0012$ & $0.0066 \pm 0.0023$ & $0.0009 \pm 0.0002$ & $0.0014 \pm 0.0006$ \\
\hline Tyr & n.d. ${ }^{\mathrm{d}}$ & n.d. & n.d. & n.d. \\
\hline Pro-Phe-Arg & $0.0043 \pm 0.0021$ & n.d. & n.d. & $0.0032 \pm 0.0009$ \\
\hline
\end{tabular}

${ }^{\mathrm{a}}$ Specific activity expressed as $\mu \mathrm{mol}$ of substrate $\mathrm{h}^{-1} \mathrm{mg}^{-1}$ of protein.

${ }^{\mathrm{b}}$ ESB230: Lactobacillus paracasei subsp. paracasei; ESB136: Leuconostoc mesenteroides subsp. mesenteroides; ESB117: Lactococcus lactis subsp. lactis; ESB50: Enterococcus faecium.

${ }^{\mathrm{c}} \mathrm{NBZ}=N$-benzoyl; pNA $=p$-nitroanilide.

${ }^{\mathrm{d}}$ n.d. $=$ not detected.

hydrolysed only by CFE of $L b$. paracasei ESB 230 . These specific activities tend to be lower than aminopeptidase specific activities pertaining to $\mathrm{CFE}$ of $L b$. paracase $\mathrm{ESB}$ 230 and Leuc. mesenteroides ESB 136, but they tend to be similar for CFE of L. lactis ESB 117 and Ent. faecium ESB 50.

\subsection{Endopeptidase activity}

The results for the endopeptidase activity of CFE of the LAB tested are depicted in Table 3. The substrate NBZ-Arg-pNA was hydrolysed by all CFE, at rates (considering conditions of saturation by substrate) similar to those prevailing during hydrolysis by dipeptidyl aminopeptidases; conversely, NBZ-Tyr-pNA was not degraded by any of the CFE tested. The CFE of $L b$. paracasei ESB 230 and Ent. faecium ESB 50 were able to attack NBZ-Pro-Phe-Arg-pNA, but the CFE of Leuc. mesenteroides ESB 136 and L. lactis ESB 117 were not.

\subsection{Dipeptidase activity}

The results for the dipeptidase specific activity of CFE of the LAB tested are depicted in Table 4. Inspection of this table indicates that the dipeptidase activities of all CFE were higher than their aminopeptidase activities, except toward those dipeptides containing Pro residues; no activity whatsoever was detected on Gly-Pro. The prolinase and prolidase activities of all CFE were low when compared with other activities on some of the dipeptides tested, but they were at a level similar to that characterising aminopeptidase activities; an exception to this rule was the CFE of Lb. paracasei ESB 230, which exhibited higher prolinase (Pro-Leu and Pro-Met) and prolidase (Phe-Pro) activities than the other CFE, and which were higher than those of aminopeptidases. The CFE of Lb. paracasei ESB 230 and Leuc. mesenteroides ESB 136 displayed the highest activities on the dipeptides Leu-Ser and Trp-Leu, followed by those activities on the peptides Ala-Phe and Met-Gly. On the other hand, the CFE of L. lactis ESB 117 and Ent. faecium ESB 50 exhibited the highest activities on the dipeptides Phe-Gly and Met-Gly, followed by those on the dipeptides Lys-Leu, Trp-Leu and Ala-Phe.

\subsection{Carboxypeptidase activity}

The results for the carboxypeptidase activity of CFE of the LAB tested are displayed in Table 5. The three 
Table 4

Dipeptidase specific activity ${ }^{\text {a }}$ (average \pm standard error) of crude cell-free extract (CFE) of lactic acid bacteria isolated from Serra da Estrela cheese

\begin{tabular}{|c|c|c|c|c|}
\hline \multirow[t]{2}{*}{ Substrate } & \multicolumn{4}{|c|}{ Lactic acid bacteria $\mathrm{CFE}^{\mathrm{b}}$} \\
\hline & ESB230 & ESB136 & ESB117 & ESB50 \\
\hline Pro-Gly & $0.0102 \pm 0.0029$ & $0.0072 \pm 0.0027$ & $0.0357 \pm 0.0058$ & $0.0460 \pm 0.0149$ \\
\hline Pro-Leu & $0.2114 \pm 0.0545$ & $0.0007 \pm 0.0009$ & $0.0138 \pm 0.0030$ & $0.0280 \pm 0.0088$ \\
\hline Pro-Met & $0.2179 \pm 0.0618$ & $0.0458 \pm 0.0147$ & $0.0268 \pm 0.0059$ & $0.1075 \pm 0.0389$ \\
\hline Gly-Pro & n.d. ${ }^{\mathrm{c}}$ & n.d. & n.d. & n.d. \\
\hline Phe-Pro & $0.1151 \pm 0.0268$ & $0.0247 \pm 0.0085$ & $0.0213 \pm 0.0038$ & $0.0169 \pm 0.0064$ \\
\hline Val-Pro & $0.0357 \pm 0.0083$ & $0.0205 \pm 0.0072$ & $0.0175 \pm 0.0030$ & $0.0251 \pm 0.0087$ \\
\hline Leu-Ser & $2.2607 \pm 0.6147$ & $2.5911 \pm 0.9188$ & $0.2463 \pm 0.0394$ & $0.5802 \pm 0.1760$ \\
\hline Lys-Leu & $0.1456 \pm 0.0362$ & $0.3304 \pm 0.1112$ & $1.0290 \pm 0.2350$ & $2.3325 \pm 0.6677$ \\
\hline Trp-Leu & $2.2828 \pm 0.5984$ & $0.6229 \pm 0.2010$ & $2.1581 \pm 0.4029$ & $1.5924 \pm 0.4938$ \\
\hline Phe-Gly & $0.3367 \pm 0.0900$ & $0.1797 \pm 0.0566$ & $4.0054 \pm 0.9017$ & $5.7483 \pm 1.9225$ \\
\hline Ala-Phe & $1.5421 \pm 0.3465$ & $0.5235 \pm 0.1553$ & $1.4152 \pm 0.2580$ & $3.3577 \pm 0.9399$ \\
\hline Tyr-Phe & $0.2136 \pm 0.0543$ & $0.1500 \pm 0.0466$ & $0.1925 \pm 0.0408$ & $0.4588 \pm 0.1401$ \\
\hline Gly-Tyr & $0.2303 \pm 0.0595$ & $0.1994 \pm 0.0606$ & $0.1205 \pm 0.0245$ & $0.1577 \pm 0.0540$ \\
\hline Arg-Val & $0.2074 \pm 0.0502$ & $0.0467 \pm 0.0158$ & $0.3961 \pm 0.0650$ & $0.3187 \pm 0.0845$ \\
\hline Glu-Val & $0.1015 \pm 0.0271$ & $0.1608 \pm 0.0512$ & $0.1366 \pm 0.0251$ & $0.2215 \pm 0.0635$ \\
\hline Met-Gly & $1.2884 \pm 0.2992$ & $0.5560 \pm 0.1873$ & $3.0145 \pm 0.7922$ & $8.1614 \pm 3.1266$ \\
\hline
\end{tabular}

${ }^{\text {a }}$ Specific activity expressed as $\mu \mathrm{mol}$ of substrate $\mathrm{h}^{-1} \mathrm{mg}^{-1}$ of protein.

${ }^{\mathrm{b}}$ ESB230: Lactobacillus paracasei subsp. paracasei; ESB136: Leuconostoc mesenteroides subsp. mesenteroides; ESB117: Lactococcus lactis subsp. lactis; ESB50: Enterococcus faecium.

${ }^{\mathrm{c}}$ n.d. $=$ not detected.

Table 5

Carboxypeptidase specific activity ${ }^{\mathrm{a}}$ (average \pm standard error) of crude cell-free extract (CFE) of lactic acid bacteria isolated from Serra da Estrela cheese

\begin{tabular}{lllll}
\hline HIP-substrate $^{\mathrm{c}}$ & \multicolumn{2}{l}{ Lactic acid bacteria CFE $^{\mathrm{b}}$} & & \\
\cline { 2 - 5 } & ESB230 & ESB136 & ESB117 & ESB50 \\
\hline Arg & $0.0195 \pm 0.0048$ & $0.0039 \pm 0.0016$ & $0.0125 \pm 0.0061$ & $0.0207 \pm 0.0093$ \\
Phe & $0.0123 \pm 0.0038$ & $0.0249 \pm 0.0087$ & $0.0129 \pm 0.0031$ & $0.1082 \pm 0.0344$ \\
Arg-Gly & $0.0182 \pm 0.0054$ & $0.0264 \pm 0.0089$ & $0.0133 \pm 0.0031$ & $0.0213 \pm 0.0075$ \\
\hline
\end{tabular}

${ }^{\mathrm{a}}$ Specific activity expressed as $\mu \mathrm{mol}$ of substrate $\mathrm{h}^{-1} \mathrm{mg}^{-1}$ of protein.

${ }^{\mathrm{b}}$ ESB230: Lactobacillus paracasei subsp. paracasei; ESB136: Leuconostoc mesenteroides subsp. mesenteroides; ESB117: Lactococcus lactis subsp. lactis; ESB50: Enterococcus faecium.

${ }^{\mathrm{c}} \mathrm{HIP}=$ Hippuryl

substrates tested were hydrolysed by all four CFE, but the carboxypeptidase activities were lower than the dipeptidase ones. Additionally, CFE of $L b$. paracasei ESB 230 and Leuc. mesenteroides ESB 136 exhibited values of activities similar to those of aminopeptidase, whereas CFE of L. lactis ESB 117 and Ent. faecium ESB 50 exhibited higher activities.

\section{Discussion}

The CFE of the four strains of LAB isolated from Serra da Estrela cheese are quantitatively, in terms of peptide hydrolysis, not so active as other LAB isolated from cheeses (El-Shafei et al., 1990; El-Abboudi et al., 1991; El-Soda, Macedo, \& Olson, 1991; Requena et al., 1993; Dako, El-Soda, Vuillemard, \& Simard, 1995).
The CFE of Lactococcus lactis ESB 117 possessed at least one aminopeptidase, one dipeptidase, one prolinase and one prolidase, as found in CFE of Lactococcus spp. by several researchers (Requena et al., 1993; Bockelmann, 1995; Fox \& McSweeney, 1996). Additionally, this extract was apparently not well equipped to release the $\mathrm{N}$-terminal proline residue, although it possessed carboxypeptidase activity; note that both these properties are atypical of Lactococcus spp. in commercial starter cultures (Baankreis \& Exterkate, 1991; Fox \& McSweeney, 1996). However, adventitious L. lactis subsp. lactis IFPL 359 was also found not to express iminopeptidases (Requena et al., 1993), and L. lactis subsp. cremoris SK11 hydrolysed Pro-pNA very slowly (Lee, Lo, \& Warthesen, 1996). Finally, the dipeptidyl aminopeptidase and endopeptidase activities of CFE of L. lactis ESB 117 were practically non-existent, even 
though these enzymes can be found in this bacterium (Christensen et al., 1999).

The substrate specificity of the peptide hydrolase system of CFE of Lactobacillus paracasei ESB 230 is similar to that described by El-Abboudi et al. (1991) and Requena et al. (1993) in that it possesses aminopeptidase (with Leu-pNA and Lys-pNA being hydrolysed preferentially), dipeptidase and carboxypeptidase activities, but not iminopeptidase activity. Additionally, the highest dipeptidyl aminopeptidase specific activities were exhibited toward Arg-Pro-pNA and Gly-Pro-pNA; hence, it appears that said CFE possesses an X-prolyl dipeptidyl aminopeptidase. Considering the substrates tested, the peptide hydrolase system of CFE of $L b$. paracasei ESB 230 was shown to be less specific and more active than that of L. lactis ESB 117 in terms of aminopeptidase, dipeptidyl aminopeptidase and endopeptidase, whereas they appeared to be less distinct in terms of dipeptidase and carboxypeptidase.

The CFE of Leuc. mesenteroides ESB 136 exhibited aminopeptidase, dipeptidase, endopeptidase and carboxypeptidase activities, but not iminopeptidase activity. These results are not in full agreement with those reported by El-Shafei et al. (1990) and El-Soda et al. (1991), who indeed did not observe carboxypeptidase activities, but found iminopetidase activity. Finally, the peptide hydrolase system of CFE of Leuc. mesenteroides ESB 136 was similar in terms of substrate specificity, but distinctly lower in terms of overall activity than that of CFE of Lb. paracasei ESB 230.

Information pertaining to the peptide hydrolase systems of Enterococcus spp. is limited. In our study, the CFE of Ent. faecium ESB 50 presented essentially dipeptidase and carboxypeptidase activities; the aminopeptidase and the dipeptidyl aminopeptidase activities were, conversely, practically non-existent.

An overview of the profile of the peptidase activities of the four strains tested indicates that their CFE cleaved preferentially peptide bonds between amino acid residues containing hydrophobic side chains (viz. Leu, Met and Phe) or basic side chains (viz. Arg and Lys); both of these are normally associated with flavour development (Lee et al., 1996).

\section{Acknowledgements}

To FCT-Program PRAXIS XXI, for the fellowship granted to Angela C. Macedo (BPD/20158/99) and for funding through project IMPACTO - Investigação para o Melhoramento da Produção de queijo serra da estrelA integrando abordagens Científicas e TecnOlógicas.

\section{References}

Baankreis, R., \& Exterkate, F. A. (1991). Characterisation of a peptidase from Lactococcus lactis ssp. cremoris HP that hydrolyses di- and tripeptides containing proline or hydrophobic residues as the amino-terminal amino acid. Systematic and Applied Microbiology, 14, 386-392.

Bockelmann, W. (1995). The proteolytic system of starter and nonstarter bacteria: components and their importance for cheese ripening. International Dairy Journal, 5(8), 977-994.

Christensen, J. E., Dudley, E. G., Pederson, J. A., \& Steele, J. L. (1999). Peptidases and amino acid catabolism in lactic acid bacteria. Antonie van Leeuwenhoek, 76, 27-246.

Cogan, T. M., \& Hill, C. (1995). Cheese starter cultures. In P. F. Fox (Ed.), Chemistry, physics and microbiology (pp. 193-257). London: Chapman \& Hall.

Dako, E., El-Soda, M., Vuillemard, J. C., \& Simard, R. E. (1995). Autolytic properties and aminopeptidase activities of lactic acid bacteria. Food Research International, 28(5), 503-509.

El-Abboudi, M., El-Soda, M., Pandian, S., Barreau, M., Trépanier, G., \& Simard, R. E. (1991). Peptidase activities in debittering and nondebittering strains of lactobacilli. International Dairy Journal, $1(1), 55-64$.

El-Shafei, H., El-Soda, M., \& Ezzat, N. (1990). The peptide hydrolase system of the Leuconostoc. Journal of Food Protection, 53(2), $165-169$.

El-Soda, M., \& Desmazeaud, M. J. (1982). Les peptide-hydrolases des lactobacilles du groupe Thermobacterium. I. Mise en évidence de ces activities chez Lactobacillus helveticus, L. acidophilus, L. lactis et L. bulgaricus. Canadian Journal of Microbiology, 28(10), 1181-1188.

El-Soda, M., Macedo, A., \& Olson, N. (1991). Aminopeptidase and dipeptidyl aminopeptidase activities of several cheese related microorganisms. Milchwissenschaft, 46(4), 223-226.

Folkertsma, B., \& Fox, P. F. (1992). Use of Cd-ninhydrin reagent to assess proteolysis in cheese during ripening. Journal of Dairy Research, 59(2), 217-224.

Fox, P. F., \& McSweeney, P. L. H. (1996). Proteolysis in cheese during ripening. Food Reviews International, 12(4), 457-509.

Lee, K. D., Lo, C. G., \& Warthesen, J. J. (1996). Removal of bitterness from the bitter peptides extracted from Cheddar cheese with peptidases from Lactococcus lactis subsp. cremoris SK11. Journal of Dairy Science, 79(9), 1521-1528.

Macedo, A. C., Malcata, F. X., \& Hogg, T. A. (1995). Microbiological profile in Serra ewes' cheese during ripening. Journal of Applied Bacteriology, 79(1), 1-11.

Ohnishi, S. T., \& Barr, J. K. (1978). A simplified method of quantitating proteins using the biuret and phenol reagents. Analytical Biochemistry, 86(4), 193-197.

Prato, O. S., \& Messina, G. (1990). Richerche sulla microbiologia del formagio. In: Istituto Sperimentale Lattiero-Caseario (Ed.), II Provolone e altre paste filate (p. 56). Lodi: La Moderna.

Requena, T., Pelaez, C., \& Desmazeaud, M. J. (1991). Caracterization of lactococci and lactobacilli isolated from semi-hard goat's cheese. Journal of Dairy Research, 58, 137-145.

Requena, T., Pelaez, C., \& Fox, P. F. (1993). Peptidase and proteinase activity of Lactococcus lactis, Lactobacillus casei and Lactobacillus plantarum. Zeitschrift für Lebensmittel Untersuchung und Forschung, 196(4), 351-355.

Tavaria, F. K., \& Malcata, F. X. (1998). Microbiological characterization of Serra da Estrela cheese throughout its AOP region. Journal of Food Protection, 6(5), 601-607.

Thomas, T. D., \& Pritchard, G. G. (1987). Proteolytic enzymes and dairy cultures. FEMS Microbiology Reviews, 46, 245-268. 